\title{
Alcohol Dehydrogenase (ADH) Isoenzymes and Aldehyde Dehydrogenase (ALDH) Activity in the Sera of Patients With Liver Cancer
}

\author{
Wojciech Jelski, ${ }^{1 *}$ Bogdan Zalewski, ${ }^{2}$ and Maciej Szmitkowski ${ }^{1}$ \\ ${ }^{1}$ Department of Biochemical Diagnostics, Medical University, Bialystok, Poland \\ ${ }^{2}$ Department of Second General Surgery, Medical University, Bialystok, Poland
}

\begin{abstract}
The principal enzymes catalyzing the conversion of ethanol to acetate are alcohol dehydrogenase (ADH) and aldehyde dehydrogenase (ALDH). The activities of these enzymes are elevated in the serum during the course of alcoholism or cirrhosis. In previous investigations we have found elevated levels of ADH, ALDH, and class I $\mathrm{ADH}$ activity in liver cancer cells. It can suggest that these changes may be reflected by enzyme activity in the serum. In this work, the activity of ADH isoenzymes, and ALDH in the sera of patients with liver cancer was measured. Serum samples were taken from 64 patients (28 drinkers, 36 nondrinkers), with liver cancer. 25 patients had primary and 39 metastatic liver tumors. Total ADH activity was measured by photometric method with p-nitrosodimethylaniline (NDMA) as a substrate and ALDH activity by the fluorimetric method with 6-methoxy-2-naphtaldehyde as a substrate. For the measurement of the activity of class I and II isoenzymes we employed the fluorimetric methods, with class-specific fluorogenic substrates. The activity of class III ADH was measured by

the photometric method with formaldehyde and class IV with m-nitrobenzaldehyde as a substrate. A statistically significant increase of class I ADH isoenzymes was found in the sera of cancer patients. The median activity of this class isoenzyme in the total cancer group increased about $51 \%$ (2.94 $\mathrm{mU} / \mathrm{L})$ in the comparison to the control level $(1.43 \mathrm{mU} / \mathrm{L})$. The activity of the class I $\mathrm{ADH}$ isoenzyme was significantly higher in the sera of patients with metastatic tumors than with primary cancers. The activity of this class in the sera of drinkers and group of moderate drinkers was significantly higher in comparison to the control group and higher in the sera of heavy drinkers when compared with moderate drinking patients. The total $\mathrm{ADH}$ activity was significantly higher (44\%) among patients with cancer than healthy ones. The activity of class I ADH isoenzymes was elevated only in the serum of patients with metastatic liver cancer. This increase of activity seems to be caused by the enzyme released from liver cancer cells and primary tumors originating in other organs. J. Clin. Lab. Anal. 22:204-209, 2008. (c) 2008 Wiley-Liss, Inc.
\end{abstract}

Key words: alcohol dehydrogenase isoenzymes; aldehyde dehydrogenase; liver cancer

\section{INTRODUCTION}

The most important enzymes responsible for alcohol metabolism are alcohol dehydrogenase (ADH) and aldehyde dehydrogenase (ALDH), which catalyze the oxidation of ingested ethanol to acetaldehyde and then to acetate respectively (1). ADH comprises a family of enzymes that has been grouped into several classes. In humans, the first two classes are mainly located in the liver parenchymal cells. Class I ADH is the classical liver $\mathrm{ADH}$ but is also observed to a lesser extent in the gastrointestinal tract, kidneys, and lungs (2). Class II $\mathrm{ADH}$ is detected only in the liver, whereas class III was found in all examined tissues (3). Class IV isoenzyme of $\mathrm{ADH}$ is expressed preferably in the upper part of digestive tract $(4,5)$. In humans, liver ALDH exists as several isoenzymes that differ in their subcellular location, electrophoretic mobility, and kinetic properties. These isoenzymes are usually divided into two

\footnotetext{
*Correspondence to: W. Jelski, M.D., Department of Biochemical Diagnostics, Medical University, Waszyngtona 15 A, PL-15-269, Bialystok, Poland. E-mail: zdb@amb.edu.pl

Received 12 September 2007; Accepted 17 February 2008 DOI $10.1002 /$ jcla. 20241

Published online in Wiley InterScience (www.interscience.wiley.com).
} 
broadly defined groups: cytosolic high $\mathrm{K}_{\mathrm{m}}$ ALDH and mitochondrial low $\mathrm{K}_{\mathrm{m}} \mathrm{ALDH}$, based upon their Michaelis constant for acetaldehyde (6).

Some authors note that serum total ADH activity is an indicator of intrahepatic cholestasis $(7,8)$. Moreover, the activity of $\mathrm{ADH}$ and its isoenzymes in the serum may be primarily elevated during liver cell injury, e.g., cirrhosis, viral hepatitis, and alcoholism $(9,10)$. In preliminary, still unpublished studies, we have shown that ADH and its isoenzymes and ALDH activities are present in the liver cancer cells. In addition, the activities of total ADH, ALDH, and class I ADH were significantly higher in cancer cells than in healthy tissues. The aim of this study was to investigate the activity of ADH isoenzymes and ALDH in the sera of patients with liver cancer.

\section{MATERIALS AND METHODS}

\section{Patients}

Serum samples were taken for routine biochemical investigations from 64 patients (44 men, 20 women, mean age 59 years, range $34-76$ years; mean age of men 63 years, range 3476 years; mean age of women 58 years, range 42-73 years) with hepatocellular carcinomas or metastatic liver tumors (Table 1). Using the tumornode-metastasis (TNM) data obtained from tumor and lymph node status, the patients were categorized according to the American Joint Committee on Cancer Classification (AJCC). A total of 17 patients had primary and 27 metastatic liver tumors. The clinical diagnosis of the disease was performed on the basis of clinical (ultrasonography and liver biopsy) and laboratory investigations. The histological study indicated that all patients were diagnosed as having adenocarcinoma. Secondary liver tumors originated in the pancreas (11), intestine (eight), stomach (five), kidneys (two), and in the lungs (one).

For the analysis, patients were divided into two groups: moderate drinkers ( 18 men with mean alcohol intake of less than $20 \mathrm{~g} /$ day and 14 women with mean alcohol intake of less than $10 \mathrm{~g} /$ day) and heavy drinkers (26 men with mean alcohol intake of more than $20 \mathrm{~g} /$ day and two women with mean alcohol intake of more than $10 \mathrm{~g} /$ day).

The control group comprised of 64 volunteers (44 men and 20 women, mean age 57 years, range $31-69$ years). The control group included 28 heavy drinkers ( 26 men, two women) and 36 moderate drinkers ( 20 men and 16 women).

The protocol was approved by the Human Care Committee of the Medical University in Bialystok, Poland (Approval No. R-I-002/47/2007). All patients gave an informed consent for the examination.
TABLE 1. Characteristics of liver cancer patients

\begin{tabular}{|c|c|}
\hline Variable & Number of patients \\
\hline Liver cancer patients & 64 \\
\hline \multicolumn{2}{|l|}{ Gender } \\
\hline Males & 44 \\
\hline Females & 20 \\
\hline \multicolumn{2}{|l|}{ Age } \\
\hline$<65$ years & 46 \\
\hline 65 years & 18 \\
\hline Range & $34-76$ \\
\hline Hepatocellular carcinoma & 25 \\
\hline Solitary & 6 \\
\hline Multifocal & 19 \\
\hline \multicolumn{2}{|l|}{ Tumor size } \\
\hline$<3 \mathrm{~cm}(1-3 \mathrm{~cm})$ & 8 \\
\hline$\geq 3 \mathrm{~cm}(3-6.5 \mathrm{~cm})$ & 17 \\
\hline \multicolumn{2}{|l|}{ Depth of tumor invasion } \\
\hline $\mathrm{T} 1$ & 6 \\
\hline $\mathrm{T} 2$ & 7 \\
\hline T3 & 7 \\
\hline $\mathrm{T} 4$ & 5 \\
\hline \multicolumn{2}{|l|}{ Lymph node metastases } \\
\hline No & 16 \\
\hline N1 & 9 \\
\hline \multicolumn{2}{|l|}{ Distant metastases } \\
\hline M0 & 16 \\
\hline M1 & 9 \\
\hline \multicolumn{2}{|l|}{ Viral hepatitis } \\
\hline Type B & 2 \\
\hline Type C & 9 \\
\hline Without viral hepatitis & 14 \\
\hline Secondary tumors & 39 \\
\hline Solitary & 11 \\
\hline Multifocal & 28 \\
\hline \multicolumn{2}{|l|}{ Tumor size } \\
\hline$<3 \mathrm{~cm}(1-3 \mathrm{~cm})$ & 11 \\
\hline$\geq 3 \mathrm{~cm}(3-7 \mathrm{~cm})$ & 28 \\
\hline \multicolumn{2}{|l|}{ Depth of tumor invasion } \\
\hline $\mathrm{T} 1$ & 6 \\
\hline $\mathrm{T} 2$ & 8 \\
\hline $\mathrm{T} 3$ & 12 \\
\hline $\mathrm{T} 4$ & 13 \\
\hline \multicolumn{2}{|l|}{ Lymph node metastases } \\
\hline No & 14 \\
\hline N1 & 25 \\
\hline \multicolumn{2}{|l|}{ Distant metastases } \\
\hline M0 & 0 \\
\hline M1 & 39 \\
\hline \multicolumn{2}{|l|}{ Viral hepatitis } \\
\hline Type B & 2 \\
\hline Type C & 0 \\
\hline Without viral hepatitis & 36 \\
\hline \multicolumn{2}{|l|}{ Amount of alcohol intake } \\
\hline Abstainers & 4 \\
\hline Moderate & 32 \\
\hline Males: less than $20 \mathrm{~g} /$ day $=140 \mathrm{~g} / \mathrm{wk}$ & 18 \\
\hline Females: less than $10 \mathrm{~g} / \mathrm{day}=70 \mathrm{~g} / \mathrm{wk}$ & 14 \\
\hline Heavy drinkers & 28 \\
\hline \multicolumn{2}{|l|}{ Time from diagnosis } \\
\hline$<3$ months & 36 \\
\hline 3-6 months & 28 \\
\hline
\end{tabular}




\section{Biochemical Assays}

\section{Determination of total ADH activity}

Total ADH activity was estimated by the photometric method with p-nitrosodimethylaniline (NDMA) as a substrate (11). The reaction mixture $(2 \mathrm{~mL})$ contained serum $(100 \mu \mathrm{L}), 1.8 \mathrm{~mL}$ of a $26 \mu \mathrm{M}$ solution of substrate in $0.1 \mathrm{M}$ of sodium phosphate buffer, $\mathrm{pH} 8.5$, and $0.1 \mathrm{~mL}$ of a mixture containing $0.25 \mathrm{M}$ n-butanol and $5 \mathrm{mM}$ nicotinamide adenine dinucleotide (NAD). The reduction of NDMA was monitored at $440 \mathrm{~nm}$ on a Shimadzu UV/VIS 1202 spectrophotometer (Shimadzu Europa GmbH, Duisburg, Germany).

\section{Determination of total ALDH activity}

ALDH activity was measured using the fluorogenic method based on the oxidation of 6-methoxy-2-naphtaldehyde to the fluorescent 6-methoxy-2 naphtoate (12).The reaction mixture contained $60 \mu \mathrm{L}$ of serum, $60 \mu \mathrm{L}$ of substrate, $20 \mu$ of $11.4 \mathrm{mmol} / \mathrm{L} \mathrm{NAD}$, and $2.8 \mathrm{~mL}$ of $50 \mathrm{mmol} / \mathrm{L}$ of sodium phosphate buffer, $\mathrm{pH}$ 8.5. The mixture contained also $50 \mu \mathrm{L}$ of a $12 \mathrm{mmol} / \mathrm{L}$ solution of 4-methylpyrazole as a specific inhibitor of ADH activity. The fluorescence was read at an emission wavelength of $360 \mathrm{~nm}$ with excitation wavelength of $310 \mathrm{~nm}$ on a Shimadzu RF-5301 spectrofluorophotometer (Shimadzu Europa GmbH).

\section{Determination of class I and II ADH isoenzymes}

Class I and II ADH isoenzyme activities were measured using fluorogenic substrates (4-methoxy-1naphthaldehyde for class I and 6-methoxy-2-naphthaldehyde for class II) in reduction reaction according to Wierzchowski et al. (13). The assays were performed in a reaction mixture containing $60 \mu \mathrm{L}$ serum, $150 \mu \mathrm{L}$ of $300 \mu \mathrm{mol} / \mathrm{L}$ substrate, $100 \mu \mathrm{L}$ of $1 \mathrm{mmol} / \mathrm{L} \mathrm{NADH}$, and $2,69 \mathrm{~mL}$ of $0.1 \mathrm{M}$ of sodium phosphate buffer, $\mathrm{pH}$ 7.6, in conditions previously described (4). The measurements were performed on a Shimadzu RF-5301 spectrofluorophotometer at emission wavelength of $370 \mathrm{~nm}$ for class I and $360 \mathrm{~nm}$ for class II isoenzymes at excitation wavelength of $316 \mathrm{~nm}$ for both substrates.

\section{Determination of class III ADH isoenzyme}

The assay mixture for class III ADH contained a serum $(100 \mu \mathrm{L})$, formaldehyde as a substrate $(100 \mu \mathrm{L}$ of $1 \mathrm{mmol})$, glutathione $(100 \mu \mathrm{L}$ of $1 \mathrm{mmol})$, and NAD $(240 \mu \mathrm{L}$ of $1.2 \mathrm{mmol})$ in $0.1 \mathrm{~mol} \mathrm{NaOH}$-pyrophosphate buffer, $\mathrm{pH} 8.0$ (14). The final volume was $2 \mathrm{~mL}$. The reduction of NAD was monitored at $340 \mathrm{~nm}$ and $25^{\circ} \mathrm{C}$ on a Shimadzu UV/VIS 1202 spectrophotometer.

\section{Determination of class IV ADH isoenzyme}

Class IV ADH activity was assayed by measuring oxidation of NADH at $340 \mathrm{~nm}$ on a Shimadzu UV/VIS 1202 at $25^{\circ} \mathrm{C}$ in a cell containing $50 \mu \mathrm{L}$ serum, $132 \mu \mathrm{L}$ of $80 \mu \mathrm{mol} / \mathrm{L} \mathrm{m}-$ nitrobenzaldehyde, and $172 \mu \mathrm{L}$ of $86 \mu \mathrm{mol} / \mathrm{L}$ $\mathrm{NADH}$, in $0.1 \mathrm{~mol} / \mathrm{L}$ sodium phosphate buffer, $\mathrm{pH} 7.5$ (15).

\section{Statistcal Analysis}

A preliminary statistical analysis (chi-squared test) revealed that the distribution of $\mathrm{ADH}$ and $\mathrm{ALDH}$ activities did not follow a normal distribution. Consequently, the Wilcoxon test was used for statistical analysis. Data are presented as median, range, and mean values. Statistically significant differences were defined as comparisons resulting in $P<0.05$.

\section{RESULTS}

The activities of ADH, ALDH, and isoenzymes of ADH in the sera are demonstrated in Table 2. The total activity of ADH was significantly higher $(44 \%)$ in patients with liver cancer than in healthy subjects $(P<0.001)$. The median total activity of $\mathrm{ADH}$ was $1713 \mathrm{mU} / \mathrm{L}$ in the patient group and $967 \mathrm{mU} / \mathrm{L}$ in the control group. The analysis of ALDH activity did not indicate significant difference between the total tested group and healthy controls $(P=0.583)$. The comparison of ADH isoenzymes activities showed that the high difference was exhibited by class I ADH. The median activity of this class in the total cancer group increased about $51 \%(3.07 \mathrm{mU} / \mathrm{L})$ in comparison to the control level $(1.51 \mathrm{mU} / \mathrm{L})$. Classes III and IV of ADH isoenzymes had higher activities in the serum of patients with cancer, but the differences were not statistically significant $(P>0.05)$.

Total serum ADH activity was significantly higher (approximately three-fold) in patients with secondary tumors than in controls. In contrast, there were no marked differences in activity of ALDH between patients with tumors (primary and secondary) and the control group. The analysis of tested activities between primary and metastatic tumors indicate significant differences in activity of total ADH and class I ADH isoenzymes.

The activities of total ADH differed significantly (by $33 \%$ ) for heavy drinkers with liver cancer in comparison to moderate drinkers tested group $(2,398 \mathrm{mU} / \mathrm{L}$ vs. $1620 \mathrm{mU} / \mathrm{L}$ ) (Table 3). In contrast, the analysis of ALDH activity did not show a significant difference between heavy drinkers with cancer and moderate drinking patients. Significantly higher class I ADH activity was found in the sera of heavy drinkers with cancer $(3.43 \mathrm{mU} / \mathrm{L})$ in comparison to moderate drinkers with cancer $(2.73 \mathrm{mU} / \mathrm{L})$. The activity of total and class I ADH isoenzymes significantly differ when compared heavy drinking or moderate drinking patients 
TABLE 2. ADH and ALDH activity in the sera of patients with liver cancer ${ }^{\dagger}$

\begin{tabular}{|c|c|c|c|c|c|c|}
\hline Tested group & $\begin{array}{l}\text { ADH I median } \\
\text { (range) }\end{array}$ & $\begin{array}{l}\text { ADH II median } \\
\text { (range) }\end{array}$ & $\begin{array}{l}\text { ADH III median } \\
\text { (range) }\end{array}$ & $\begin{array}{l}\text { ADH IV median } \\
\text { (range) }\end{array}$ & $\begin{array}{l}\text { ADH total median } \\
\text { (range) }\end{array}$ & $\begin{array}{l}\text { ALDH median } \\
\text { (range) }\end{array}$ \\
\hline $\begin{array}{l}\text { Liver cancer } \\
(n=64)\end{array}$ & $3.07(0.72-5.46)$ & $15.34(6.97-22.05)$ & $11.13(6.56-18.42)$ & $5.66(2.84-10.89)$ & $1713(846-3267)$ & $3.45(1.34-6.94)$ \\
\hline $\begin{array}{l}\text { Primary tumor } \\
(\mathrm{n}=25)\end{array}$ & $2.13(0.72-3.99)$ & $15.22(6.97-19.26)$ & $10.66(6.56-16.12)$ & $5.45(2.84-9.99)$ & $1594(846-2689)$ & $3.39(1.34-6.07)$ \\
\hline $\begin{array}{l}\text { Metastatic tumor } \\
\quad(\mathrm{n}=39)\end{array}$ & $3.95(1.87-5.46)$ & $15.76(7.23-22.05)$ & $12.45(8.02-18.42)$ & $6.72(3.27-10.89)$ & $2725(972-3267)$ & $3.96(1.65-6.94)$ \\
\hline Control $(n=64)$ & $1.51(0.65-4.34)$ & $15.85(7.21-23.62)$ & $10.94(7.05-17.93)$ & $5.34(2.77-10.17)$ & $967(382-2289)$ & $3.02(1.29-6.66)$ \\
\hline \multicolumn{7}{|l|}{$P$} \\
\hline $\begin{array}{l}\text { Liver } \\
\text { cancer vs. } \\
\text { control }\end{array}$ & $<0.001^{*}$ & 0.553 & 0.672 & 0.357 & $<0.001^{*}$ & 0.583 \\
\hline $\begin{array}{l}\text { Primary } \\
\text { cancer vs. } \\
\text { control }\end{array}$ & 0.259 & 0.478 & 0.098 & 0.443 & 0.184 & 0.257 \\
\hline $\begin{array}{l}\text { Metastatic } \\
\text { cancer vs. } \\
\text { control }\end{array}$ & $<0.001^{*}$ & 0.724 & 0.534 & 0.675 & $<0.001^{*}$ & 0.553 \\
\hline $\begin{array}{l}\text { Primary cancer } \\
\text { vs. metastatic } \\
\text { cancer }\end{array}$ & $<0.001^{*}$ & 0.794 & 0.663 & 0.685 & $<0.001^{*}$ & 0.663 \\
\hline
\end{tabular}

${ }^{\dagger}$ Data are expressed as $\mathrm{mU} / \mathrm{L}$. Bold $P$ values are statistically significant.

TABLE 3. The activity of ADH isoenzymes and ALDH in the serum of heavy drinkers and moderate drinkers with liver cancer ${ }^{\dagger}$

\begin{tabular}{|c|c|c|c|c|c|c|}
\hline Tested group & $\begin{array}{l}\text { ADH I } \\
\text { median } \\
\text { (range) }\end{array}$ & $\begin{array}{l}\text { ADH II } \\
\text { median } \\
\text { (range) }\end{array}$ & $\begin{array}{c}\text { ADH III } \\
\text { median (range) }\end{array}$ & $\begin{array}{l}\text { ADH IV } \\
\text { median (range) }\end{array}$ & $\begin{array}{l}\text { ADH total } \\
\text { median (range) }\end{array}$ & $\begin{array}{l}\text { ALDH } \\
\text { median } \\
\text { (range) }\end{array}$ \\
\hline \multicolumn{7}{|l|}{ Heavy drinkers $(\mathrm{n}=28)$} \\
\hline With liver cancer & $\begin{array}{c}3.43 \\
(1.09-5.46)\end{array}$ & $\begin{array}{c}15.74 \\
(7.47-22.05)\end{array}$ & $\begin{array}{c}11.54 \\
(7.54-18.42)\end{array}$ & $\begin{array}{c}5.94 \\
(3.02-10.89)\end{array}$ & $\begin{array}{c}2398 \\
(980-3267)\end{array}$ & $\begin{array}{c}3.62 \\
(1.49-6.94)\end{array}$ \\
\hline Without liver cancer & $\begin{array}{c}1.94 \\
(0.83-4.34)\end{array}$ & $\begin{array}{c}15.77 \\
(7.51-23.62)\end{array}$ & $\begin{array}{c}11.28 \\
(7.33-17.93)\end{array}$ & $\begin{array}{c}5.45 \\
(2.95-10.17)\end{array}$ & $\begin{array}{c}1135 \\
(468-2289)\end{array}$ & $\begin{array}{c}3.14 \\
(1.56-6.66)\end{array}$ \\
\hline $\begin{array}{l}P \\
\text { With liver cancer vs. without } \\
\text { liver cancer } \\
\text { Moderate drinkers }(\mathrm{n}=32)\end{array}$ & $<0.001$ & 0.368 & 0.569 & 0.415 & $<0.001$ & 0.486 \\
\hline With liver cancer & $\begin{array}{c}2.73 \\
(0.86-4.94)\end{array}$ & $\begin{array}{c}15.12 \\
(6.97-20.34)\end{array}$ & $\begin{array}{c}11.52 \\
(6.56-17.95)\end{array}$ & $\begin{array}{c}5.11 \\
(2.78-10.64)\end{array}$ & $\begin{array}{c}1620 \\
(846-2785)\end{array}$ & $\begin{array}{c}3.31 \\
(1.34-6.31)\end{array}$ \\
\hline Without liver cancer & $\begin{array}{c}1.33 \\
(0.65-3.94)\end{array}$ & $\begin{array}{c}15.65 \\
(7.21-21.09)\end{array}$ & $\begin{array}{c}11.13 \\
(7.05-17.77)\end{array}$ & $\begin{array}{c}4.98 \\
(2.77-9.74)\end{array}$ & $889(382-1963)$ & $\begin{array}{c}2.88 \\
(1.29-6.04)\end{array}$ \\
\hline \multicolumn{7}{|l|}{$P$} \\
\hline $\begin{array}{l}\text { With liver cancer vs. without } \\
\text { liver cancer. }\end{array}$ & $<0.001^{*}$ & 0.572 & 0.432 & 0.655 & $<0.001^{*}$ & 0.636 \\
\hline $\begin{array}{l}\text { Heavy drinkers with liver } \\
\text { cancer vs. moderate drinkers } \\
\text { with liver cancer }\end{array}$ & $<0.001^{*}$ & 0.431 & 0.667 & 0.248 & $<0.001^{*}$ & 0.745 \\
\hline
\end{tabular}

${ }^{\dagger}$ Data are expressed as $\mathrm{mU} / \mathrm{L}$. Bold $P$ values are statistically significant.

with control group. There were no marked differences in activities of other tested ADH isoenzymes between heavy drinkers and moderate drinkers with liver cancer.

\section{DISCUSSION}

It is commonly accepted that changes of enzyme activity in the hepatocytes in the course of different liver diseases are reflected by increase of the corresponding enzyme activity in the serum. Moreover, cellular injury and necrosis leads to the release of cytoplasmic enzymes. For example, the activities of aminotransferases correlate with the severity of the condition and their monitoring is a diagnostic marker of liver cells injury during viral hepatitis (16). According to the data obtained by Mezey and Cherrick (17) the elevated serum activity of ADH reflects damage to liver parenchymal cells. In our last study we found that 
$\mathrm{ADH}$ and its isoenzymes and ALDH activities are present in the liver cancer cells. Moreover, we also showed that the total activity of ADH cancer tissue is about $20 \%$ higher than that in healthy liver. The activity of class I ADH is significantly higher in cancer cells than in normal liver tissues (our unpublished results). In this study we found that the serum total ADH activity has been changed in the course of liver cancer. The increase of total ADH activity was positively correlated with class I ADH so the cause for the increase of total ADH in the course of this cancer is an elevation of class I ADH isoenzymes. Class I ADH is also present in the gastrointestinal tract, kidneys, and lungs, but up to $95 \%$ of this activity is found in the liver. So the elevated activity of class I ADH seems to be caused by the isoenzymes released from cancer cells or from liver cells damaged by tumor. The activity of class I ADH isoenzymes is significantly higher in the serum of patients with metastatic cancer than with primary cancer. Metastatic cancers are infiltrating tumors that aggressively act on liver tissue and lead to the release of the enzyme from normal liver cells. These results are in agreement with data reported by Chrostek and Szmitkowski (18), which showed a higher class I ADH activity in metastatic tumor than in primary cancer. Our study also demonstrates that the activity of class IV ADH and class III ADH are not significantly different in the serum of patients with secondary liver cancer. High activity of class IV ADH was characterized in gastric cancer cells, and the activity of class III ADH in the pancreatic cancer cells was about $30 \%$ higher than that in normal pancreatic tissues $(19,20)$. In our study, metastatic liver tumors also originated in the both organs. The elevated activity of these isoenzymes seems to be caused by the enzyme released from cancer cells originating in the stomach and pancreas. Serum activity of class II ADH isoenzymes, appeared to have even a tendency to decrease in liver cancer. Class II ADH is present only in the liver and we have found that the activity of this class is insignificantly very slightly higher in hepatocellular carcinoma than in healthy tissues (our unpublished results).

It is known that chronic alcohol abuse is an important factor in hepatic dysfunction. We observed that the activity of class I ADH isoenzymes was significantly higher in the serum of heavy drinkers with liver cancer than in moderate drinkers patients. Our results are also similar to those of Chrostek et al. (21), who found much higher class I ADH isoenzymes activity in the sera of alcoholics. The pretreatment staging procedures included chest X-ray and computed tomography (CT) and blood examinations. The bilirubin concentration and activities of enzymes (alanine aminotransferase, aspartate aminotransferase, and $\gamma$-glutamyltransferase), tested as markers of liver lesions, were significantly elevated. Thus in our results the elevated serum activity of class I ADH in drinkers may derive from the liver. In contrast, the serum activity of other tested classes of ADH isoenzymes in patients with cancer does not significantly differ between heavy drinkers and moderate drinkers. It is interesting that it concerns class II ADH, which is only liver-specific isoenzyme. The activity of class II ADH is unchanged in the serum of the heavy drinkers with liver cancer. Moreover it is similar to that observed in nonalcoholic cirrhosis and in other liver diseases $(8,9)$. This class of isoenzymes increases only during acute viral hepatitis (10).

In our preliminary study we found that the activity of ALDH was significantly higher in cancer cells than in healthy hepatocytes. But the present study demonstrates that the serum levels of ALDH is not different between patients with liver cancer and the healthy group. This would suggest that ALDH is not released from liver cancer cells. This probably happens because a remarkable part of the total ALDH activity is found in microsomal and mitochondrial fractions (22).

In conclusion, we can state that the activity of class I, III, and IV of ADH isoenzymes was elevated in the serum of patients with liver cancer regardless of whether primary or secondary cancers were analyzed, but solely class I ADH was significantly higher only in the patients with metastatic cancer. We have to consider that the activity of class III and IV ADH derived from primary cancers originating in the pancreas and stomach, but class II ADH is released only from liver cells, whereas an approximately three-fold increase of serum activity of class I isoenzymes seems to be caused by the enzyme released from liver cancer cells (primary and secondary) and primary tumors originating in all other organs. The serum activity of class I ADH probably reflects the amount of cancer tissue in the whole body.

\section{REFERENCES}

1. Lieber CS. Metabolism of alcohol. Clin Liver Dis 2005;9:1-35.

2. Maly IP, Toranelli M, Sasse D. Distribution of alcohol dehydrogenase isoenzymes in human liver acinus. Histochem Cell Biol 1999;111:391-397.

3. Koivusalo M, Baumann M, Uotila L. Evidence for the identity of glutathione-dependent formaldehyde dehydrogenase and class III alcohol dehydrogenase. FEBS Lett 1989;257:105-109.

4. Jelski W, Chrostek L, Szmitkowski M, Laszewicz W. The activity of class I, II, III and IV of alcohol dehydrogenase isoenzymes in gastric mucosa. Dig Dis Sci 2002;47:1554-1557.

5. Yin S-J, Wang M-F, Liao C-S, Wu C-W. Identification of a human stomach alcohol dehydrogenase with distinctive kinetics properties. Biochem Int 1990;22:829-835.

6. Goedde HW, Agarwal DP. Polymorphism of aldehyde dehydrogenase and alcohol sensitivity. Enzyme 1987;37:29-44.

7. Mezey E, Cherrick GR. Serum alcohol dehydrogenase: an indicator of intrahepatic cholestasis. N Engl J Med 1968;279:241-248. 
8. Chrostek L, Szmitkowski M. Activity of class I and II isoenzymes of alcohol dehydrogenase measured by a fluorometric method in the sera of patients with obstructive jaundice. Clin Chim Acta 1997;263:117-122.

9. Chrostek L, Szmitkowski M. Human alcohol dehydrogenase isoenzyme activity in the sera of non-alcoholic liver cirrhotic patients. Eur J Clin Chem Clin Biochem 1996;34:801-804.

10. Chrostek L, Szmitkowski M. Serum class I and II alcohol dehydrogenase activity during the course of viral hepatitis. Eur J Clin Chem Clin Biochem 1995;33:825-829.

11. Skursky L, Kovar J, Stachova M. A sensitive assay for alcohol dehydrogenase activity in blood serum. Anal Biochem 1979; 89:65-71.

12. Jelski W, Zalewski B, Chrostek L, Szmitkowski M. The activity of class I, II, III and IV of alcohol dehydrogenase (ADH) isoenzymes and aldehyde dehydrogenase (ALDH) in the colorectal cancer. Dig Dis Sci 2004;49:977-981.

13. Wierzchowski J, Dafeldecker WP, Holmquist B, Vallee BL. Fluorimetric assay for isozymes of human alcohol dehydrogenase. Anal Biochem 1989;178:57-62.

14. Koivusalo M, Baumann M, Uotila L. Evidence for the identity of glutathione-dependent formaldehyde dehydrogenase and class III alcohol dehydrogenase. FEBS Lett 1989; 257: $105-109$.
15. Dohmen K, Baraona E, Ishibashi H, et al. Ethnic differences in gastric $\sigma$-alcohol dehydrogenase activity and ethanol first pass metabolism. Alcohol Clin Exp Res 1996;20:1569-1576.

16. Ferard G, Imbert-Bismut F, Messous D, et al. Influence of pyridoxal phosphate in measuring aminotransferases activities in patients with viral hepatitis. Ann Biol Clin 2004;62:717-720.

17. Mezey E, Cherrick GR. Serum alcohol dehydrogenase: an indicator of intrahepatic cholestasis. N Engl J Med 1968;279:241-248.

18. Chrostek L, Szmitkowski M. The activity of class I and II alcohol dehydrogenase isoenzymes in the sera of patients with liver tumours. Clin Chem Lab Med 2000;38:409-412.

19. Jelski W, Chrostek L, Szmitkowski M. The activity of classes I, III, and IV of alcohol dehydrogenase isoenzymes and aldehyde dehydrogenase in gastric cancer. Dig Dis Sci 2007;52:531-535.

20. Jelski W, Chrostek L, Szmitkowski M. The activity of classes I, II, III, and IV of alcohol dehydrogenase isoenzymes and aldehyde dehydrogenase in the pancreatic cancer. Pancreas 2007;35: 142-146.

21. Chrostek L, Szmitkowski M, Wierzchowski J. Activity of class I and II alcohol dehydrogenase in the sera of alcoholics. Eur J Clin Chem Clin Biochem 1994;32:881-884.

22. Koivisto T, Eriksson JP. Hepatic aldehyde and alcohol dehydrogenases in alcohol-preferring and alcohol-avoiding rat lines. Biochem Pharmacol 1994;48:1551-1558. 